Notre Dame Law School

NDLScholarship

Journal Articles

Publications

2005

\title{
Foundations of Practical Reason Revisited
}

John M. Finnis

Notre Dame Law School, john.m.finnis.1@nd.edu

Follow this and additional works at: https://scholarship.law.nd.edu/law_faculty_scholarship

Part of the Legal History Commons, and the Natural Law Commons

\section{Recommended Citation}

John M. Finnis, Foundations of Practical Reason Revisited, 50 Am. J. Juris. 109 (2005).

Available at: https://scholarship.law.nd.edu/law_faculty_scholarship/868

This Article is brought to you for free and open access by the Publications at NDLScholarship. It has been accepted for inclusion in Journal Articles by an authorized administrator of NDLScholarship. For more information, please contact lawdr@nd.edu. 


\section{FOUNDATIONS OF PRACTICAL REASON REVISITED}

\section{JOHN FINNIS}

One's investigations, reflections and communications are actions. Sometimes they are simply spontaneous, but very often, as with other kinds of action, one needs to opt into them by deliberation, choice and continued effort, all of which make noticeable one's responsiveness to opportunities. This paper revisits some main elements in that responsiveness.

Doing law immerses one both in practical reason's activities, thinking about what to choose and do, and in a certain amount of reflection on the content and structure of that thinking. As Aquinas says, laws whether highly general or very specific are all "universal propositions of practical reason." From the beginning of one's legal studies, especially in a common-law jurisdiction, one is working to identify the propositions of law that are correct for the jurisdiction (let us say, "valid"). To oneself and others, one shows both the content and the correctness of these propositions by referring to further propositions, picking out conditions for the validity of a proposition of law conditions some of which jurists call sources of (this jurisdiction's) law and others of which they call principles of interpretation. Some nineteenth and twentieth century legal theories, such as those of John Austin and Hans Kelsen, could be taken to imply that the conditions for legal validity all concern form and originating fact: forms of transaction or process, such as enactment by the dateable activities of a particular legislature. And that position has initial appeal to lawyers, used as they are to seeking the "root of title" in forms of dateable transaction such as sale, conveyance, registration, and the like. But it has turned out to be both mistaken and self-defeating to deny that criteria or premises for judging propositions of law valid or not valid, correct or not correct, characteristically do, and need, to refer also to content, to considerations concerning the kind of conduct that the proposition whose validity is in question purports to direct or authorize, or concerning the ways in which other propositions of law may or do direct or authorize such conduct.

Theories making that denial err in supposing that an account of law's validation could describe or explicate something recognizable-or worth having —as legal thought and practice unless it acknowledged the centrality

1. Summa Theologiae I-II q. 90 a. 1 ad 2. 
to legal thought and practice of such content-based criteria as that (i) purportedly valid propositions of law must not contradict or be practically inconsistent with each other, and (ii) the propositions validated by particular, dateable legal transactions remain valid unless and until some invalidating event, and (iii) later transactions and their normative products prevail over earlier transactions and their products of the same kind. None of those criteria is entailed by any factual propositions or originating events, and none is a requirement of logic (for no requirement of logic excludes the sober judgment that such and such a community, and indeed each of its members, is simply confused, and/or that its rulers enact contradictory rules in order to confuse their subjects).

And theories seeking to expel from "juristic science" all non-formal criteria of validation defeat their own descriptive-explanatory purposes. In any community the criteria of validation employed by its law will be found to make reference to such content-based considerations as that the law's subjects need to be given coherent and practicable directions, that the law needs to change from time to time, that the law's requirements and authorizations should be ascertainable by its subjects in advance, that disputes should be settled, transactions and their putting into effect be facilitated, wrongs righted, reasonable expectations respected, fraud discouraged, and so forth. Criteria of content such as the general principles of law I have just mentioned are sometimes, and reasonably, called principles of interpretation. They shape any jurist's understanding of statements and other originating events purporting to validate propositions of law in this or that particular jurisdiction, and equally shape any juristic assessment of that purported validity. All these general criteria, and even more so the more specified institutions and rules giving effect to them in the different ways we find in different communities, presuppose positions about what would be good for the community in question, and what would be harmful to it (instability, uncertainty, irresolvable disputes, absence of opportunity to make arrangements that will order future events, unresponsiveness to new threats and opportunities, and so forth).

In short: the law's sources include not only relevant judgments of the higher courts, applicable statutes and constitutional documents, writings of jurists, and principles and structures of logic, but also general principles articulating what seem to one, in one's legal thinking-as they have seemed to many others - to be requirements of civilized, decent, humanly appropriate behaviour. And even to understand a legal system, let alone to participate in upholding, applying and developing one, is to engage with practical reason, in a manner that invites awareness of, and opportunity for reflection upon, its structure, shape, process, criteria, and logic as a set of reasons for action that count as (legal) reasons because of their place in that legal system's overall 
project of directively picking out of prospective goods and ways to attain them, prospective harms and ways to avoid them. Sometimes, indeed, this reference to goods and harms is direct and immediate; more commonly, I think, it is to be discerned only by "tracing back" the specific proposition of law to the principles from which it is "derived," principles articulating such a reference as a part of the rational process of interpretation and validation by which, as good lawyers, we can make clear the justification for affirming that such and such (" $p$ ", and "It is part of our law that $p$ ") is indeed a valid or true proposition of law (that is, of the law of this jurisdiction at least).

\section{II}

So a lawyer, particularly in the common law tradition, ${ }^{2}$ can readily find congenial an account of practical reason such as Aquinas offered in his discussion of law, treating every human positive law as a proposition derived from practical reason's very first principles, whether by way of "conclusion" or, much more commonly, by the non-deductive but rational specification that he calls determinatio. ${ }^{3}$

2. Jurists in the modern civilian (Roman Law-based) tradition are inclined to call the subject-matter of their discipline droit or derecho or diritto, Recht, ius, "right," terms which their tradition of interpretative theory contrasts with lex and its derivatives loi, ley, "law". Undeniably, what is just as between persons in relation to some matter is law's direct concern. But such relationships are not so fundamental that they cannot be explicated and shown to be just(ified) by reference to the principles of practical reason-the most universal true propositions about what is or is not to be done. Unfortunately, even the English tradition of translating and interpreting Aquinas became corrupted on this point, as is indicated by the quite erroneous Dominican translation of Aquinas's statement that lex is aliqualis ratio iuris as "law is an expression of right" when the obvious and correct translation is something like "law is (in the nature of) a foundation of or informing idea behind right(s)"-just as, Aquinas's preceding sentences explain, the ratio of a building is what pre-exists in the mind of the builder and regulates (provides the "rule" for) the building-work. Summa Theologiae II-II q. 57 a. 1 ad 2: “...sicut eorum quae per artem exterius fiunt quaedam ratio in mente artificis praeexistit quae dicitur regula artis, ita etiam illius operis iusti quod ratio determinat quaedam ratio praeexistit in mente, quasi quaedam prudentiae regula....ideo lex non est ipsum ius, proprie loquendo, sed aliqualis ratio iuris." The sentence here replaced by ellipses muddies the waters by recalling the specialized Roman-law sense of lex as something written, but the argument as a whole is clear, and should control any translation of ratio iuris.

3. On determinatio see Summa Theologiae I-II q. 96 a. 4c; Finnis, Natural Law \& Natural Rights, 282-290, 295-296; "On 'The Critical Legal Studies Movement', American Journal of Jurisprudence 30 (1985) 21-42; also in Oxford Essays in Jurisprudence: Third Series, ed. John Bell and John Eekelaar (Oxford: Clarendon Press, 1987), 145-65; "Natural Law \& Legal Reasoning," in Natural Law Theory: Contemporary Essays, ed. Robert P. George (Oxford: Clarendon Press, 1992), 134-157; "The Truth in Legal Positivism," in The Autonomy of Law: Essays on Legal Positivism, ed. Robert P. George (Oxford: Clarendon Press, 1996), 195-214. 
But there can be no question of simply accepting Aquinas's account, whether because it is his, or because it incorporates Aristotle's (and Plato's), or because it fits some main aspects of one's lawyerly habits of thought. Everything in it has been challenged, and needs to be reappropriated-if and to the extent that it deserves to be-by thinking through the challenges and denials it confronts.

It is commonly supposed that the easy way to show what is meant by "practical reason" or "rationally required" is to point to cases where opting for and doing or achieving $X$ will get one what one wants-will satisfy one's desire, or one's here and now dominant desire. The necessity of means to an end established in and by one's desiring it is taken to be paradigmatic practical necessity, practical rationality, and normativity (at least practical as distinct from, say, logical normativity). Such thoughts can be given the label Humeian, or neo-Humeian, and so they are, ${ }^{4}$ but Hume himself gives disconcerting voice to their implication for the very idea of practical reason:

'Tis not contrary to reason for me to prefer the destruction of the whole world to the scratching of my finger. 'Tis not contrary to reason for me to choose my total ruin to prevent the least uneasiness of an Indian or person wholly unknown to me. 'Tis as little contrary to reason to prefer even my own acknowledged lesser good to my greater, and have a more ardent affection for the former than the latter. A trivial good may, from certain circumstances, produce a desire superior to what arises from the greatest and most valuable enjoyment....

Hume's claim here struck me long ago as more like an admission about what his account of reason entails. It is that my being deflected by this desire for a trivial good from doing what is required to get the greatest and most valuable enjoyment for myself, or to save everyone (or the whole world) from destruction, is not contrary to reason. That is to say, "prudence," in the thin modern sense of self-interest, is no more rationally required, or even rationally motivated, than morality in the thin modern sense that gets its content by an implied contrast with self-interest.

Nor is this a matter of Hume being carried away by love of paradox or rhetorical effect. This is just one of several ways in which Hume denies or is committed to denying that there is practical reason, in favor of a picture in

4. They are also more than neo-Humeian, so pervasive are their sources and influence; for the neo-Kantian and Weberian (not to mention Nietzschean) elements in "the modern fact-value distinction" and the alleged "positivity of values," see my reflections on Anthony Kronman's Max Weber (Stanford, California: Stanford University Press, 1983) in my “On 'Positivism' and 'Legal Rational Authority'," Oxford Journal of Legal Studies 5 (1985) 74-90.

5. David Hume, A Treatise of Human Nature, ed. L.A. Selby-Bigge, rev. P.H. Nidditch (Oxford University Press, 1978), 416 (emphasis added). 
which we simply do whatever we do, and what one actually does, in each successive situation, shows what it was that one was desiring (wanting) most-shows what was one's (dominant) end and the means one judged available and sufficiently efficacious. In such a picture there is simply no room for normativity, for being guided or directed to adopt certain means (by reason of their efficacy for one's end(s)) which, however, one might (irrationally or at least unreasonably) fail to adopt. All that counts is one's current dominant desire, which may well be the desire to avoid the burdens and/or bad side-effects of the means necessary to attain what was, until a moment ago, one's dominant desire. The is of "is what I at this moment most desire," like the is of "is what I was most desirous of until a moment ago" (and, for that matter, the is of "my intelligence is of the kind that finds means to ends"), provides no ground for an ought. Thus a mechanics of desire (in the end reducible to something as crude as Hobbes depicts) has eliminated all the conceptual space which might have been occupied by practical reason. A reason that is slave to desire can indicate canny ways to satisfy some of one's desires but gives no reasons for action.

These implications of the Humeian position were methodically and effectively traced in Christine Korsgaard's critique (1997) of the standard assumptions about the normativity of instrumental reason, and more particularly about the normativity or practical rationality of (self-interested) prudence. $^{6}$ There she reached a strong but, I think, justified conclusion. There can be no practical rationality at all-no even hypothetical imperatives, no rationally required means-unless there are "some rational principles determining which ends are worthy of preference or pursuit," "normative principles directing the adoption of ends," "something which gives normative status to our ends" by giving "unconditional reasons for having certain ends, and, it seems, unconditional principles from which those reasons are derived." (One might put it like this: If reasons did not go all the way down, there is no way they could enter directively into our deliberations at all.) For "unless something attaches normativity to our ends, there can be no requirement to take the means to them." ${ }^{10}$ Such ends, moreover, have to be "good, in some sense that goes beyond the locally desirable." "For "I must

6. "The Normativity of Instrumental Reason," in Ethics \& Practical Reason, ed. Garrett Cullity and Berys Gaut (Oxford: Oxford University Press, 1997), 215-54.

7. Korsgaard, "Normativity", 230.

8. Ibid., 250.

9. Ibid., 252.

10. Ibid., 251.

11. Ibid., 250-251. Korsgaard, at 251, 252, is tempted to resile from this to allow for a "heroic existentialist act" of "just tak[ing] one's will at a certain moment to be normative, and 
have something to say to myself about why I am [willing an end, and am committed and remain committed to it, even in the face of desires that would distract and weaknesses that would dissuade me]-something better [to say to myself], moreover, than the fact that this is what I wanted yesterday"12 (or indeed a moment ago or even, in the struggle of feelings, "locally," right now).

We might summarize Korsgaard's observations by saying: basic reasons for willing-for choosing and carrying out one's choice-state what is good about what the action intends, and good in a way that could be said to give unconditional reason for acting in pursuit of such good(s) or at least with an eye to avoiding what would negate such good(s). Such good-identifying reasons are unconditional, I take her to mean, not in the sense that they are "categorical" or "moral" but in the sense that they are non-dependent, not in need of justificatory or validating explanation-primary, intrinsic, basic.

III

Still, the question whether we are in a position to specify the basic reasons for willing and doing and consider them together, as a set, is one that (so far as I am aware) Korsgaard, like most other contemporary philosophers, abstains from framing or answering. In her case, the abstinence may be connected with the philosophical tradition within which she explicitly places herself. The influence of this tradition-so important if we are to understand much modern theology, too-can be seen when in her Oxford lectures of 2002 she takes up the question whether or not (as she formulates it) "desires and inclinations are simply responses to the good-making properties of objects, and it is only the good-making properties of objects that we need to talk about when we talk about our reasons, not the desires and inclinations themselves." Her answer is: "as a Kantian, I disagree" with that picture in two ways. First, "in Kant's view [i] the features of the objects we desire that we mention when we explain why we value those objects would not give those objects value were it not for the way in which those features are related to human physiology and psychology. [ii] At the basis of every desire or inclination, no matter how articulately we can defend it, is a basic suitableness-to-us that is a matter of nature and not of reason. [iii] Value is relational and what it is related to is our nature." As to this first way of disagreeing, I would remark that the three propositions she here identifies as Kant's view all seem to me,

commit[ting] oneself forever to the end selected at that moment", "for no other reason that that [one] wills it so". But she should concede that unless such a person considers that there is something worthwhile in doing so, some good in or reason for doing so, such an "act of commitment" and of subsequent "taking as normative" is not rational but irrational.

12. Ibid., 250. 
as they are stated, sound, save for the contrast implied in "of nature and not of reason"; and none of them gives a sufficient reason for doubting that intelligent desires and inclinations are responses to the good-making properties of possible objects of desire, deliberation and choice. As to her second way, it again appeals directly to that specific tradition and its master:

As a Kantian I believe that it is our own choices that ultimately confer value on objects, even though our choices are responsive to certain features of those objects.

I interject to suggest that part of the problem Korsgaard is making for herself arises from the ambiguity of "object." In the older tradition which Kantian (or at least Kant's) thought seeks both to support and to contest, the objects of one's choice are (i) one's actions, (ii) the states of affairs that actions can instantiate or otherwise bring about, and (iii) the consequent fulfillment (in part if not in whole) of persons that is the ultimate point of actions and their intended effects. In such an understanding of the term "object," there is no plausibility to the thought that our choices, in responding to some feature of an object, confer value upon it. Still less would there be plausibility to it if the term object is taken to include a person who might be benefited or harmed by my choice and action. But to return to Korsgaard's second point:

In choosing objects, in conferring value on things that answer to our nature in welcome ways, an agent is affirming her own value. She takes what matters to her to matter absolutely and so to be worthy of her choice.

[We can return to these questionable sentences in a moment, after letting Korsgaard add her own well-judged caveats.]

But even if the agent herself believes this Kantian theory, it doesn't follow that she must think of herself as choosing objects simply because she wants or likes them. She can still talk to herself, and to others, about what she likes about them, and why. So even though there is a sense, on my account, in which we choose things "because we want them", a sense in which the inclination provides the reason, it doesn't follow that when someone asks you

[and that someone might well be "the agent herself," as Korsgaard's earlier rendering of the point recalled: "I must have something to say to myself..."]

[when someone asks you] why you chose something, [it doesn't follow that] "I wanted it" is the right answer. ... [W] [hen you are explaining your values to another person, it is quite uninformative to mention the fact that you have an inclination for the object as the basis of the value. He knows that... [H]e wants 
to know which inclination you are having, what is drawing you to the object. And you specify that by describing, as far as you can, the incentive [that is, by giving a motivationally-loaded representation of the object, presenting the object as desirable or aversive in some specific way..$^{13}$

Taking the passage as a whole, and giving full weight to the well-judged caveats that are its concern after its first three sentences, I wonder if there is not here another instance of what one finds in the full shadow of the Enlightenment: Hume founding everything in (what we innocently think of as) practical reason on desires that happen to be built into our nature, our "human physiology and psychology"; Kant denying that that can account for the rational force, the normativity (prescriptivity or directiveness), of any reasons for action, and ascribing that normativity to reason's self-legislation; Korsgaard taking this to be a matter of "committing oneself" to ends, but Kant being unable to give any fundamental account of which ends it is intelligent and reasonable to commit oneself to. And all the while the lateAristotelians of the time (like some still today) are unable to provide the help that flickers momentarily into view with Korsgaard's idea of "a basic suitableness-to-us that is a matter of nature"; for, not unlike the passage from her Oxford lecture, they treat this as "a matter of nature and not of reason," 14 having lost touch with the foundational epistemological insight of Aristotle and Aquinas that I regret not articulating as such in Natural Law \& Natural

13. Christine M. Korsgaard, Self-Constitution: Action, Identity, and Integrity (The John Locke Lectures, 2002) Lecture Four, "Expulsion from the Garden: the Transition to Humanity," 4.4.4 with 4.1.1 (http://www.people.fas.harvard.edu/ korsgaar/Korsgaard.LL4.pdf).

14. For another, complementary statement of some deficiencies in the neo-Aristotelean tradition, see my Fundamentals of Ethics (Oxford: Clarendon Press, 1983), 32 where, having shown Anthony Kenny advancing the view that there are "some desires which are beyond questioning, which simply exist as 'natural facts' about me or about everyone, and which make practical reasoning and reasonableness possible without themselves being matters of reason or understanding at all," I went on:

Here we obviously have rejoined Hobbes and Hume. But not just Hobbes and Hume.

A whole school of interpreters of Aristotle has claimed that when Aristotle said 'deliberation is of means not ends' he meant to ally himself with those who maintain that the basic ends of our action are provided not by our intelligent grasp of certain objectives as truly good, but rather by the desires with which human nature equips us, or which we simply happen to have. And that school of interpreters has found supporters among the many neo-scholastics who thought they were following Aquinas when they said that prudentia concerns means not ends, and that synderesis (the other aspect of reason mentioned by Aquinas in this connection) is a matter not of understanding ends but of intuiting moral truths about the fitting or the obligatory, i.e. about certain conditions on the pursuit of ends (the ends of human action being then supposed to be given by subrational 'inclinations').

(Emphases in original) 
Rights: a nature such as ours is known by understanding the objects that make sense of the acts by which the capacities of a being of such a nature are realized. ${ }^{15}$

The resulting Enlightened confusion is epitomized by the oscillation in this passage of Korsgaard's, between (a) the idea of "conferring value on things that answer to our nature in welcome ways," (b) the contrary idea that their answering to our nature makes them valuable prior to our choice, and makes our choice of them intelligent and (in principle) reasonable, and (c) the idea that as agents we have a value of our own that is to be "affirmed"-which might mean merely alleged (freely asserted and therefore freely deniable), but may more naturally mean judged to be what it truly is.

What is to be made of the thought that in action one is "affirming one's own value"? First: as I am sure she takes for granted, it would be unreasonable of me simply to assert, without reason, that while I have my own value, and what matters to me matters "absolutely and so [is] worthy of my choice," nevertheless you and everyone else do not have that kind of value, and what matters to you and others does not matter in the same kind of way. So if it were not evident-self-evidently assertible-that others, at least some others, and what matters to them, are of value in a way that counts as giving me unconditional (if not categorical or obligatory) reason for acting in favor of them, the thought that I and my concerns have such value would have no purchase. Second: Korsgaard's own sound arguments against Humeian misconstruals, with the resultant willy nilly overthrow, of practical reason show well enough that no mere desire or resolve of mine to treat myself and what matters to $m e$ as of inherent ("absolute") value or worth can provide any reason for my so treating myself and my attitudes and inclinations or, indeed, their objects.

Third: to say (or think) that I and the objects of my choice have value is to invite the question whether this says anything of interest, anything worthy of belief, unless it implies conditions and exclusions. To be choiceworthy, mustn't the objects of my choices have a value not predicable of the object of a drunk searching for a lamppost to serenade, or-to shift the nature of the doubt - of the object of a ruthlessly selfish and cruel conman, habitually flattering to deceive, rape, rob, and for the pleasure of it to kill? And can my value count for anything, in deliberation or reflection, unless it is other than that of such agents as a vigorous cancer, or a crocodile diving to its lair with its still living booty, someone's child, between its jaws? More pertinently still, isn't it clear that one's thoughts about the value of one's objectives, and

15. See Fundamentals of Ethics, 20-22; Aquinas: Moral, Political and Legal Theory (Oxford: Oxford University Press, 1998), 29-34, 90-94, 102. 
of the personal identity one will ineluctably shape for oneself by pursuing them, cannot be reasonably affirmed unless they could be mistaken? That they can be mistaken is something we have all learned, or at least come to presume, from experience, by the very dawn of the age of reason-by six or seven or whenever it was.

\section{IV}

Following Aquinas, and Germain Grisez's rethinking of Aquinas, and the evidence of (inter alia) empirical anthropology, Natural Law \& Natural Rights offered a list of basic reasons for willing (intelligent wanting) and doing. Jurisprudential discussions of the book have tended to focus too exclusively on the list, as if the answers to all decisive questions are here. Philosophers have tended to ignore them; many perhaps assume that so straightforward a recital could not possibly be a true response to the issues considered by Hobbes, Hume, Kant or Nietzsche, though others like Martha Nussbaum and Amartya Sen have rejected the assumption and proposed their own comparably brief and substantive lists. ${ }^{16}$ In 1995-7, Sabina Alkire put the resultant alternative though partially overlapping lists to the test of consonance with the self-understanding of women in the village of Arabsolangi in far upcountry Pakistan, as she describes in her doctoral book Valuing Freedom.

Aquinas thought of these basic reasons as the first practical principles or principles of practical reason-_"principles" both as propositions of high generality and comprehensiveness, and as sources of all intelligent thinking about what to do. They are the "principles of natural law or natural right" that lawyers are in search of. But though they are justly thought of as a kind of ending place in a lawyerlike search for the roots of law's claims, what I want to stress in the rest of this paper is that identifying and affirming them is only a beginning.

What qualities of thought and response are involved in getting from the first principles to the relatively specific judgments of a kind fit to be laws in a just political community? Some of the issues around this question have recently been explored by Terence Irwin in "The Scope of Deliberation: A Conflict in Aquinas" (1990)" and "Practical Reason Divided: Aquinas and his Critics" (1997). ${ }^{18}$ His earlier article suggested that Aquinas inconsistently holds both

16. See the ample documented discussion of their lists (and mine) in Sabina Alkire, Valuing Freedoms: Sen's Capability Approach and Poverty Reduction (Oxford: Oxford University Press, 2002).

17. Review of Metaphysics 44 (1990) 21-42.

18. In Cullity and Gaut, Ethics \& Practical Reason, 189-214. 
(A) that deliberation is always about means, not ends, and the intellectual virtue of deliberating well-prudentia-has no role in the virtuous person's identification (and adoption) of the right end or ends, which is rather a matter of that non-deliberative grasp of basic ends and first practical principles that Aquinas calls synderesis and says is shared by the virtuous and vicious alike, and at the same time (B) that prudentia does (necessarily) have a role in that identification (and adoption) of the right end or ends which distinguishes the virtuous person from the vicious. In his later article, Irwin tacitly abandons this claim about Aquinas's inconsistency, and finds the needed reconciliation in the thought that there is a "macro-prudence," the governing virtue of deliberating well about everything to do with what happiness consists in, in general (so to speak) (206); the synderesis that virtuous and vicious share tells us no more and no less (according to Irwin's synthesis) than that there is for each and all of us a "universal end" $(203,204)$, "the final good of human beings with the nature they have" (202); it is for macro-prudence to set us on the path to right action by determining that universal end and final good.

But this is not, I think, the right way to synthesize Aquinas's statements whose inconsistency (at the level of statements) has interested his friends for many centuries ${ }^{19}$-into a coherent set of propositions about the role of intellectual (but not the less moral) virtues (summarily, prudentia) in establishing the content of practical reason (and thus of ethics and sound politics). ${ }^{20}$ The "ultimate first principle of natural law" (202), does not articulate, even generically, the concept of a universal end or final good of beings with our nature. ${ }^{21}$ Aquinas's vigorous explorations of such a final end,

19. See Cajetan's commentary on Summa Theologiae I-Il q. 66 a. 3 ad 3 (Aquinas, Omnia Opera [Leonine edition], VI, p. 433). I have tried to show by some as yet unpublished reflections on the relevant passages in Aquinas how they can and should be synthesized: "A Problem about Practical Reasonableness in Aquinas" (presented, with Irwin commenting, at Chapel Hill, North Carolina, in 1998).

20. Irwin (1997) shows well how "a virtuous agent must understand (perhaps without formulating) the sorts of considerations that concern the theorist" (210).

21. Having quoted the central part of I-II q. 94 a. 2 on the first principles of practical reason, Irwin says "In this passage Aquinas refers back to his discussion of the final good (I-II qq. 1-5)." (202) But I see in q. 94 a. 2 no reference, even implicit, to that discussion of "the final good." The connection that q. 94 a. 2 makes between good and aiming is indeed "not tautologous or trivially analytic," but that is not because, in affirming the connection, Aquinas "is claiming that rational agents, in acting for the sake of the good, seek to achieve a rational structure in their aims" - or at least he is not here making or in need of an assertion about "rational structure in [one's] aims" under the description rational ordering of aims to one single final aim. The fact that qq. 1-5 seem to argue that anyone who has rationality cannot but have some such single final aim is important to Aquinas but not, I think, to q. 94 a. 2 nor even to its development in the structure of secondary principles of practical reason which are the ratio of the moral virtues and the most general principles of (for) positive law. The link affirmed in q.94 
in launching the Prima-Secundae,-explorations driven both by specifically theological concerns and premises, and by the model of Aristotle's Ethicsyield for a philosophical ethics little or no fruit beyond the paradoxical notion that there is an imperfecta beatitudo, an incomplete complete-fulfillment, which consists in living in line with the virtues. What it is to have these virtues, and how one's responsive understanding can advance from the first principles grasped in synderesis to the distinctions between morally good and bad, and virtuous and vicious choices, is left by the early sections of the Prima-Secundae in as much obscurity as Aristotle leaves the question how his discussions of eudaimonia in Ethics I and X illuminate the virtue of justice in Ethics V.

No, the "ultimate first principle of natural law," occupying the same sort of place in practical thinking as the principle of non-contradiction in all thinking, ${ }^{22}$ directs only that we act to some intelligible point, and the substantive first principles have their directiveness precisely in and by picking out the kinds of point (end, good, value) that have the requisite intelligibility -intelligibility as desirable because beneficial for anyone: life, marriage, knowledge, friendship, practical reasonableness, and likeness to and harmony (indeed, assimilatio) with the transcendent source of all reality and value. ${ }^{23}$

Anyone who has the prerequisite knowledge of cause and effect and of what is attainably possible (e.g. that questions can be answered, and answers hang together as fields of knowledge) can understand both the content and the directiveness of the propositions which pick out and direct us to favor following these basic human goods. But one cannot respond concretely to that directiveness without considering these ends in their relationship both to each other and to what might instantiate and/or effect them intelligently. For one cannot intend any kind of end, however ultimate or "macro-," without understanding it in relationship to means-to something that would promote or realize and instantiate an end of that kind: Summa Theologiae I-II q. 12 a. 4. So everything about how these basic intelligible human goods hang together and are sensibly (reasonably) realizable is matter for practical

a.2 goes through the concepts of the desirable (appetibile) and the perfective (the what makes better-off and is thus opportunity], and the tight link between these is, in the Summa Theologiae, most clearly asserted in I q. 5 a. 1 (see Natural Law and Natural Rights, 78-79).

22. Summa Theologiae I-II q. 94 a.2c ('Hoc est ergo primum principium legis, quod bonum est faciendum et prosequendum, et malum vitandum'); Finnis, Aquinas, 79-80, 86-87.

23. Here I slightly adjust Aquinas's list in S.T. I-II q. 94 aa. 2 \& 3, changing "knowledge of God" to accommodate the tight relationship he sees between the desirability of knowing God and the desirability of, in understanding him, being like him: Summa contra Gentiles III c. 25 n.1; Finnis, Aquinas, 315 and 312-315, 308-311. 
reasonableness, that is, for prudentia. ${ }^{24}$ There is no "special faculty" called synderesis. ${ }^{25}$ Rather, from end to end of practical reason(ing) there is simply one's understanding (intellectus, intelligere) with its beginnings or roots or foundation in non-deductive acts of insight into, understanding of, the data of experience, and then the effort and discipline of reasonable judgment-as in "a person of judgment." "Judgment"26 is indeed the idiomatic practical English for prudentia, which itself is nothing other than one's extending one's intelligence into mastering-by informing and guiding, with the basic goods' integral intelligibility-one's deliberations, judgments, choices, and the carrying out of one's choices in actions and the fulfillment possible in the circumstances for oneself and those whom one's actions benefit.

I agree with Irwin (and Aristotle and Aquinas) that the principles which are picked out by a philosophical ethics and which shape both that ethical theory and political/legal theory worthy of the name cannot be other than a reflectively self-aware and appropriately extended version of prudentia-of right-minded thinking about what to do with one's life including one's life as a citizen. I mention this here because the thought that one cannot do ethical/ political theory well without having the moral (and intellectual) virtue of practical reasonableness can seem arrogant, but really is a recognition that in this kind of theorizing one has a special and unavoidable vulnerability to theoretical error, namely to theoretical error arising precisely because of some regrettable defect in one's character, which entails some want of prudentia.

24. When Philippa Foot shook free from the neo-Humeanism which I pointed out as fundamental to her moral thought in my "Reason, Authority and Friendship in Law and Morals," Jowett Papers 1968-1969, ed. B.Y. Khanbhai, R.S. Katz, and R.A. Pineau (Blackwell, Oxford, 1970), 101-24 (and see her dismissive comment at p. 25) and Finnis, Fundamentals of Ethics, $28-29,62$ ), an important part of the liberation was coming to see the mistake of holding, as so many have and do, that "we come first to a theory of rational action, and then try as best we can to slot in the rationality of acts of justice and charity": "Does Moral Subjectivism Rest on a Mistake?" [her 1994 Hart Lecture at Oxford], Oxford Journal of Legal Studies 15 (1995) 1-14 at 4-5. On the mistake in what Sidgwick named and upheld as "the modern ethical view," see e.g. my remarks in Aquinas, 111 , on the theories "constructed to expound the rationality and/or natural primacy of egoistic 'prudence', and to explore the question how we may 'bridge the gap' between such prudence (on the near bank) and morality (on the farther shore)." Cf. Finnis, Natural Law and Natural Rights, 134.

25. Aquinas's very first proposition about synderesis is that it is not a potentia (but rather a habitus): S.T. I q.79 a. 12c; cf. Irwin, 201.

26. "My salad days, / When I was green in judgment...": Anthony \& Cleopatra 1.5.607; see also 1.4.555: “...boys, who, being mature in knowledge, / Pawn their experience to their present pleasure, / And so rebel to judgment"; likewise 2.2.754, 3.13.2279; and countless other places in Shakespeare's characters' reflections on character and action. It matters not at all that Cleopatra may be wrong, or merely playful, in claiming to be now less immature, less lacking in practical reasonableness. 
(Of course, one can be, so to say "academically," adept at articulating and finding one's way around an ethical system which one accepts as propositions already articulated by others, whether by a single magister or by a community, "school," or tradition, rather as if it were a legal system-just as we nowadays can be adepts of the Roman Law of, say, slavery. This needs no well developed practical reasonableness, no prudentia or other virtues. But nor is it theory, properly speaking.)

Still, it does not follow that every error or weakness in one's theorizing must be ascribed to one's moral flaws. Failure to reflect accurately upon one's deliberations and dispositions, and/or to reason from one's reflections correctly and energetically, can be the cause of oversights and errors of theoretical judgment. The account of ethics given in Natural Law and Natural Rights fails to identify what unifies and validates the intelligibility of the eight or nine principles with which its chapter on the "methodological requirements of practical reasonableness" is concerned. It should have explicated those proto-ethical principles as specifications of morality's master principle (that one should remain open, in all one's deliberating and willing, to integral fulfillment-fulfillment which is not one's own, nor indifferent to one's own, but locates it in the fulfillment of all human persons in all their communities). Such specifications give us something properly decisive to "say to [one]self" (as Korsgaard put it) in the face of those emotional motivations which would deflect us from-as distinct from those that support us in-responding with integral reasonableness to the directiveness of the basic reasons. And thus we move from the understanding, in itself pre-moral, ${ }^{27}$ of the basic human goods, the basic practical reasons, to moral distinctions and reasons - from, for example, the goods of life-in-health, and emotional-rational integrity, with their correlative bads or harms of bodily or psychosomatic loss, disharmony, and suffering, to the moral distinction between cruelty and the beneficent infliction of suffering as a side-effect of, for example, healing or rescuing.

\section{V}

This paper stays with the foundations and goes no further into either the further, intermediate principles which structure specifically moral (and properly legal) thought or the dialectic with ethical methods such as the utili-

27. "Pre-moral" does not mean "non-moral": see Aquinas, 87: “The moral sense of 'ought', understood critically, not merely conventionally, is reached... when the absolutely first practical principle is followed through, in its relationship to all the other first principles, with a reasonableness which is unrestricted and undeflected by any subrational factor such as distracting emotion. In that sense, the 'ought' of the first principles is incipiently or 'virtually', but not yet actually, moral in its directiveness or normativity." 
tarian, consequentialist or proportionalist and the legal-theoretical counterparts. ${ }^{28}$ Its theme is the first practical principles in their own progressively discoverable, unfolding content. One motive for staying with this theme is to underline one's reason's unity. Though reason directed towards deliberation and choice has its truly first and undeducible first principles, theoretical or speculative reason and practical reason are nowise two powers. In one's thinking soundly about what it would be good to do, to attain, or to become, one draws upon all one believes about what can be, is, has been, or is probable. And the understanding of such basic truths as "Knowledge is good and desirable and to be valued and pursued" - an understanding available even to those who will not deploy it appropriately-presupposes an awareness ("theoretical" if you like) of the possibility (attainability) of overcoming ignorance, an awareness which is being supplemented by the new, original, logically underived (undeduced) "practical" insight articulated in that true practical proposition. Equally, in one's thinking soundly about what kind of being we human beings are, one is drawing upon that stock of original, primary practical principles, which are thus not only the source (principium) of the normativity ${ }^{29}$ articulated in legal ${ }^{30}$ and moral thinking but a source also of our knowledge of human nature. For, to repeat, we know the nature of a dynamic reality such as ours by knowing the capacities of this kind of being, and the capacities in their turn by knowing the activities of which such beings are capable, and we understand those activities only by understanding their point-and that point is precisely what one is identifying in identifying each of the basic forms of human good.

"Identifying" is hardly an adequate term, however. What we are here concerned with is an understanding of each of these kinds of opportunity, of these desirable aspects or ways of being a human person and a human community. As I have been saying, such an understanding of opportunity is equally a perception, a becoming aware, of the normativity that, when its

28. See Natural Law and Natural Rights, 111-124; Fundamentals of Ethics, 80-135; Nuclear Deterrence, Morality and Realism, Oxford: Clarendon Press, 1987), 177-272; Moral Absolutes, 13-83; "Commensuration and Public Reason," in Incommensurability, Incomparability, and Practical Reason, ed.. Ruth Chang (Cambridge, Mass.: Harvard University Press, 1997), 215-233, 285-9.

29. There are other sources of normativity, logical, technical, and natural. But inasmuch as one's thinking in logic, technology and art, and in natural sciences as much as in the ethical and legal domains, is an action subject to one's choices, the actual conduct of thought and argument is always dependent in part upon the practical normativity entailed by the good(ness) and pursuit-worthiness of knowledge.

30. Of course, there is plenty of legal thinking that de facto merely imitates without participating in acknowledgment of the moral normativity which makes best sense of having law; but such legal thinking is non-central, however frequent it may happen to be. 
content and force is elaborated, we call moral-a becoming aware of the content as well as the rational force (normativity, directiveness) of moral propositions. The most specific and hard-edged of moral norms will be no more than a specification of what was (is) generically contained as directive in the principles that pick out the basic forms of human opportunity/perfection. So: what these basic principles contain, what these basic forms of human wellbeing truly are, is to be inquired into with zeal and care - with effort - and with all the resources of reflection, including what we lamely call fiction (say, King Lear).

What we call will is essentially one's responsiveness to one's understanding of such opportunities. (Whether Hume's teaching about reason's incapacity to motivate was the result more of his misunderstanding understanding, or of his misunderstanding human appetition's multiple layers of resource, scarcely matters: the teaching is thoroughly mistaken. ${ }^{31}$ ) In seeking to expand one's understanding of the basic kinds of opportunity open to us, one is responding - with that kind of generic interest or pro-attitude Aquinas calls voluntas simplex - to the intelligible goodness of whichever kind of good is presently the focus of one's inquiry, but one is also responding with something more focused and closer to choice, i.e. with intent, to the intelligible good of knowledge, and to the bonum rationis, the good of extending reason's motivating sway, its existential, more than merely propositional, normativity in one's own life (one's deliberating, choosing and doing) ${ }^{32}$

In the last twenty-five years, those of us engaged in the reflective practical undertakings of which Natural Law \& Natural Rights was a manifestation have tried various such explorations of basic human goods. Marriage, for example: it was not properly identified in $N L N R$, where life, transmission of life, and friendship were left in an uncertain relation. ${ }^{33}$ Reflection on the complementarity of the two sexes, and on the way that in marital acts the couple can each actualize, express, and experience their chosen commitment to marriage as the form of friendship oriented and appropriate to procreation,

31. To criticism such as Korsgaard's summarized in section III above add, for example, Robert P. George, "A Defense of the New Natural Law Theory" in In Defense of Natural Law, ed. George (Oxford: Oxford University Press, 1999), 17-30; Joseph Boyle, "Reasons for Action: Evaluative Cognitions that Underlie Motivations," American Journal of Jurisprudence 46 (2001) 177-197.

32. On bonum rationis, widely neglected in accounts and attempted reiterations of Aquinas's moral theory even though it is precisely the good to which prudentia is directly the adequate response, see Summa Theologiae I-II q. 94 aa.3 \& 4; also q. 91 a 2c, q. 93 a. 6c; Aquinas, 83-85, 98-99.

33. See Natural Law and Natural Rights, 86-87. Editors and translators of Aquinas's consideration of the basic practical principles in Summa Theologiae I-II q. 94 a. $2 \mathrm{c}$ have shown a similar failure of understanding on the matter: see Finnis, Aquinas 82, 97-98. 
has provided a good example, I think, of the sort of enhancement of understanding that I am wanting to point to here. ${ }^{34}$ And then there is that good which can be called harmony between persons, or friendship, or sociability, or even justice. The radical (foundational) equality between persons that turns out to be its very core can become understood by reflections upon such extremes in human opportunity or peril as we considered in inquiring whether final retaliation against the inhabitants of an enemy state, or strategic intra-war attack on the inhabitants of a city or other region, or the production of human beings by technical manipulation of materials, are indeed opportunities or mere temptations.

The good which occasion has prompted us to consider perhaps most closely is that of human life itself. From its beginning to its end it is nothing less or other than the very existing of the person, the human being. Aquinas, precisely when giving his fullest but not quite exhaustive list of the basic human goods, says that this good is, as existence, one that we share with all other creatures whatever. ${ }^{35}$ Though true, this would be very misleading if it made one overlook the vast differences between the existing of a molecule (or of a lake) of water, the life of a carrot, the life of a cat, and the life of a human being. For human life is the existence of a being with the radical capacities -real in their dynamism towards action even when they are prevented from actuation by immaturity, sleep, sickness, or other injury, or decay - to live in sanctity, heroism, shame, guilt...

But those are moral if not also legal categories of human character, so I will restrict my articulation of the point to more foundational categories such as meaning, truth, and freedom. Our nature as human creatures, the array of radical capacities we all have from the outset, is exemplified by how we do things with words. Certain sounds or marks, sheerly physical even when retained in imagination and memory as brain-states, convey by a kind of embodiment both understanding and intention (will to communicate this and not that or not-this) ${ }^{36}$ between persons utterly separated in every physical

34. See e.g. Germain Grisez, Way of the Lord Jesus, vol. 3, Living a Christian Life (Quincy, Illinois: Franciscan Press, 1993), ch. 9 especially sec. E; Finnis, "The Good of Marriage and the Morality of Sexual Relations: Some Philosophical and Historical Observations," American Journal of Jurisprudence 42 (1997) 97-134. To some extent it is rather a recovery by philosophy of an enhanced understanding already attained in other domains of thought

35. S.T. I-II q. 94 a.2c.

36. This dual sense of "meaning" is one of the realities being subtly evoked at The Tempest 1.2. 496-499:

When thou didst not, savage,

Know thine owne meaning; but wouldst gabble like

A thing most brutish, I endow'd thy purposes

With words that made them known: 
dimension. This communicating displays, both as effect displays cause and as an exemplary analogy, how in the being, makeup and existence of their human authors, materiality or bodiliness (physical, chemical, biological and psycho-somatic) is united with that which is as immaterial as a meaning-a notion, a proposition, a question, a purpose-shareable across continents or centuries (or the dinner table or the courtroom). As Aquinas argued, this kind of unity is best signified by taking one's soul to be the very form and act(uality) of one's body, such that it can even be said to "contain" the body and be the body's very basis. ${ }^{37}$ Here we reach the metaphysical foundation of human equality, which entails the inequality with us of all other creatures of which we have experience, all of them in truth not merely non- but subhuman, or lacking the dignity of the human because lacking a radical capacity foundational to our reality. ${ }^{38}$

In practical thinking the metaphysics of the human person-such as I have just sketchily articulated - is normally left unarticulated, outside the focus of advertence. In its place is, first, the understanding, intrinsic to the initial grasp of first practical principles, that basic goods such as knowledge, life, and friendship are good not only for me or thee, but for "anyone"; and second, the awareness or assumption that our choices and therefore our actions matter, and that we are responsible in all the four senses Hart distinguished: ${ }^{39}$ we cause effects, have at least radical capacity for care and choice, can have roles and duties of care and conduct, and consequently liability to praise or blame, for merit or guilt, which make no sense unless our unrepented free choices last in us as the intransitive, self-shaping, identity-constituting dimension of chosen action or inaction. Our interest in such multipally grounded attributions of responsibility signifies this sort of practical-cum-theoretical understanding that our existence is as beings capable of mattering now because of our subsisting individual identities each with a past as well as a future. Such transcendence of the material, in both the benefit(s) we envisage and the personal subjects we know are open to being so benefited, is part of what warrants the thought that each of us matters-matters in our life or

37. See Aquinas, 177-179; “'The Thing I am': Personal Identity in Aquinas and Shakespeare," Social Philosophy and Policy 22 (2005) 250-282 at 253-257; also in Personal Identity, ed. Ellen Frankel Paul, Fred D. Miller and Jeffrey Paul (Cambridge and New York: Cambridge University Press, 2005), 250-282 at 253-257.

38. On "radical capacity," see my "A Philosophical Case against Euthanasia," "The Fragile Case for Euthanasia: A Reply to John Harris," and "Misunderstanding the Case against Euthanasia: Response to Harris's first Reply," in Euthanasia: Ethical, Legal and Clinical Perspectives, ed. John Keown (Cambridge: Cambridge University Press., 1995), 23-35, 46-55, 62-71 at especially 30-31, 68-70.

39. H.L.A. Hart, Punishment and Responsibility (Oxford: Oxford University Press, 1968), chapter 10. 
death, health or ill health, our knowledge or our ignorance, our reasonableness or unreasonableness, our friendship or self-centredness. It is part of what warranted Elizabeth Anscombe in referring, philosophically, to "the mystical value of the human being." ${ }^{40}$ Even though she was always ready to treat a word like mystical in the way she treated Aristotle's offering talk of the bloom on the face of youth to explicate the relation between pleasure and the objective of reasonable choice-_"babbling," she called it-it is I think a better word to try to convey what needs to be acknowledged about the value of the existence of each human being than the word "absolute," which someone might take Korsgaard's account to be asserting.

We need some such awareness of human value if we are to make sense of the normative force, the directiveness of the principles of practical reason, the directiveness which they have when taken, not one first principle after another in isolation from each other and from the need to make particular choices, but in their integral directiveness under the architectonic, regulatory directiveness of the good of practical reasonableness itself-that is, when taken as morally normative. Sometimes the death of someone known to us reinforces for us that awareness. Shakespeare, who makes present to us incomparably the actuality, the sheer vitality of human lives, and whose intentions were at the same time more knowingly philosophical than is often assumed, took some real individual's death as the occasion for articulating (amongst other things!) the dependence of practical reason and its directiveness upon a responsive awareness of the value that human beings have and can enhance and diminish by their own responsiveness to it. In an enigmatic and unparalleled poem first published in 1601 and commonly known as "Phoenix and Turtle," he memorializes, as Patrick Martin and I have I think shown, ${ }^{41}$ the marriage and death of a young widow, shortly after her public execution for religion in late February 1601; he memorializes, that is to say, not only the union of wife and husband (phoenix and turtle[dove]) with each other through years of separation by the husband's exile for religion but also her constancy through the years after his death. The poem's term for this constancy and fidelity to commitment is, as was then a more common use of the words, "truth" and "true." Despite the extreme abstractness of its central "anthem," and its rigorous structuring by formalities of reasoning and of religion, what the poem centrally articulates is a grief that seems unmistakably the author's own, and a kind of awe at the costly and active loyalty of the spouses to each other (as

40. Human Life, Action and Ethics: Essays by G.E.M. Anscombe (St.Andrews Studies in Philosophy \& Public Affairs), ed. Mary Geach and Luke Gormally (London: Routledge, 2005), 260.

41. "Shakespeare's Intercession for Love's Martyr," Times Literary Supplement, 18 May 2003, 12-14; see also “"The Thing I Am'," 267-270. 
well as to what they each held most dear, held in common, and each died in miserable solitude for upholding). This couple's closeness and constancy in love, especially while divided and parted by exile, are celebrated in a series of virtuoso quasi-mathematical, quasi-metaphysical paradoxes over seven stanzas, culminating in the structure of cause-and-effect, evidence-andinference, antecedent-and-consequent that is introduced along with the poem's last quasi-personal subject, Reason itself:

Reason in itself confounded,

Saw Division grow together,

To themselves yet either neither,

Simple were so well compounded

That it cried, how true a twain,

Seemeth this concordant one,

Love hath Reason, Reason none,

If what parts can so remain. ${ }^{42}$

"Love hath Reason" is here most carefully presented as expressing Reason's own insightful judgment. Anyone who accepts a position like the one I have been arguing for or re-presenting in this paper will want to take this statement in a sense that corresponds neither to the Humeian/Weberian "desire creates reason" and "confers value upon its object," nor to the Pascalian "the heart has its reasons, which are unknown to reason." May not this poet's "Love hath Reason" be compatible with and perhaps even affirm the position that love of persons, each precisely for his or her own sake, has the reasons which the first practical principles pick out, the human goods towards which those principles direct us, each of these goods an aspect of the worth (in deprivation or fulfillment) of each human being?

Practical reason's first principles are, so to speak, transparent for the persons who can flourish in the kinds of way to which those principles direct us-so transparent that it is, in truth, those persons for whose sake we are responding when we respond at all to those reasons' summons. Such love goes all the way from the truly all-embracing "Love your neighbour as

42. Lines 41-48. The poem's anthem began in line 22 with "Love and constancy is dead," and its lament ("Threnos") will reach a not quite final conclusion in line 64 with "Truth and beauty buried be." That lament began in line 53 with "Beauty, truth and rarity, / Grace in all simplicity, / Here enclos'd in cinders lie," and ends (lines 65-8) "To this urn let those repair That are either true or fair: / For these dead birds sigh a prayer."--thus affirming that the death of this exemplary couple is neither an oblivion nor extermination. 
yourself' to particular commitment to another ${ }^{43}$-for example, the uniquely exclusive while outward-looking commitment constitutive of marital love-and is of the essence of all the practical normativity we call moral and, in proper case, legal. And for backsliders like us, the relatively few persons of heroic virtue can be a reminder, inspiring rather than depressing, that but for one's own-one's "love's" and "will's"-responsiveness to what these reasons summon us to, rational capacity would and will be for each of us nothing more than what Hume pretended it cannot but be for all, a slave of the passions that thus is, gives, and has "reason none." If the poet who was a selfeffacing maestro of judgment, and whose artistry gets its deepest force in enactments of reconciliation and fellowship, concurs in denying that the highest or deepest imperium belongs to sightless desire or aversion, we have a telling witness or advocate (not precisely an argument); but whether his work is properly understood as such concurrence is obviously a quaestio disputabilis for another day. In any event, there may be some who find more persuasive the resonance of the articulated principles with lived experience, aspirations, and efforts, not least those of poor and far upcountry villagers.

\section{POSTSCRIPT}

\section{A. Natural inclinations and first practical principles}

Patrick Lee asks me to be more forthcoming or precise about what I called the dependence of practical reason and its directives on a responsive awareness of the value that human beings have and can enhance or diminish by their own responsiveness to it. This is linked with the question (in my mind) whether Lee is right to say that, according to Aquinas, our insights into human goods, the insights articulated in first practical principles, are insights "into one's natural inclinations," inclinations which are "data for the practical insight." That is not the way I read Aquinas, nor, more importantly perhaps, is it the way things (so far as I can see) really are. Rather, I think that the practical insight, say, that knowledge is good and pursuitworthy, has as its

43. See Aquinas, 127: “'One should love one's neighbour.' But to love a person volitionally (not simply emotionally) is to will that person's good. So, to love one's neighbour is to will the neighbour's good - and not just this or that good, but good somehow integrally; and nothing inconsistent with a harmonious whole which includes one's own good (likewise integrated in itself and with others' good). Thus the love of neighbour principle tends to unify one's goals. Moreover, the love of neighbour required by this principle need not be a 'particular friendship'. (FN: The love involved in a particular friendship \{amor amicitiae\} does have at its core, however, one's willingness as a friend to treat the friend as one treats oneself (amans se habet ad amatum, in amore amicitiae, ut ad seipsum\}: II-II q. 28 a. 1 ad 2.)" 
data-the data to which the insight will add something original-the awareness not only of the urge (inclination) to question and the experience of satisfaction when a question is answered, but also the "theoretical" insight that knowledge is possible. To the experience of a question getting an answer, another getting an answer, and so on, this non-practical insight adds the original (new) understanding that there is a whole horizon of possibility (call it truth and knowledge) of which particular answers to particular questions are only instances. Only then does practical insight add the further, practical understanding that that field of possibility is also a field of opportunity, benefit, a perfection, etc. When that second, practical insight is followed through by chosen commitments to study, reflection, investigation, and so forth, one's original understandings both of knowledge's possibility and of its worth are greatly deepened and enhanced.

I think this mutual reinforcement of theoretical and practical insight is pervasive. So one's originally childish insight into the practical truth that those opportunities are opportunities for me and anyone like me, or into the opportunity of being a friend by valuing and willing the good of another or others for their own sake, is reinforced by knowledge of the capacity of myself and others to make the efforts, commitments, self-disposing devotion to others, and so forth, or to come up with the twisty rationalizations and evasions of betrayal, and so forth. On all this deepened knowledge of possibility there supervenes the enhanced practical understanding of the worth of the person for whom or by whom such acts of will and communication are possible.

\section{B. Reason and love}

Terence Irwin's commentary at our conference raised some searching questions about friendship and fulfillment or eudaimonia. He took up my explanation of "Love hath Reason, Reason none" and said: "I take [Finnis] to mean that love of persons for their own sake helps to explain how facts about human fulfillment constitute reasons that guide our actions, and thereby helps to explain normativity." And later he said that "As I understand Finnis's Shakespearean view, he assigns some sort of priority to love in the generation of reasons."

But I want to maintain, and I suggest that the poem maintains, the priority of insight and understanding of goods to every response of will, including the totalizing sort of response of friendship or amor amicitiae.

The Reason who is introduced in the poem is at first the theoretical reason which stands baffled or teased by the paradoxes of unity and difference, conceptual quasi-paradoxes such as that one is not a number, and so forth- 
and baffled too by the unity of friendship, a unity which is, I think, captured not so well by the Aristotelian notion of the friend as "another self" as by the Aristotelian notion that in friendship there is in view a truly common good not reducible to my good or thy good, and completely beyond capture by a word or phrase such as "self-interest."

And finally what Reason finds baffling is the constancy of the poem's couple in their commitment to each other and to the good of the truth which each was looking to beyond themselves. What amazes Reason is (as it says) that their unity could survive what parted them-as the poem does not explicitly say but its deciphering enables readers to know: exile, poverty, and then a death.

So I take the poem to be saying-not that Love supplies motives unknown to reason, motives which then operate in place of Reason, in Reason's place-but rather (i) that the Love exemplified in the literally exemplary couple has the true reasons (fully acknowledgeable by Reason) that are given by the worth of the persons involved, their true loveableness, but (ii) that to live up to this takes more than the intelligibility of the loveable goods instantiated in these loveable persons; it takes the wholehearted response of those persons; and (iii) that to observe by example the possibility of such devoted, constant, "true" responsiveness enables one to deepen and reinforce one's understanding of the goods of knowledge, friendship, and practical reasonableness and thus also one's understanding of the good/value of the persons whose whole lives instantiate and exemplify those goods so awesomely. Love does have reasons, but these would remain "no reason" if they remained merely intelligibilities affirmable by reason, and were not taken up, out of the fungibility of goods that can be and are instantiable in countless people, and embodied in commitment to this particular person. (Something like the same issue arises in patriotism and other forms of loyalty.) 
